に共重合体と仕込原料の組成が同一である。

よって共重合実験に於て重合率の低い最初において生 成した共重体の組成仕込原料の単量体比を求めれば $\gamma_{1}$ 就よび $\gamma_{2}$ が求められる。

これを用いてある共重合体に生じた遊離基と各単量体 との相対反応速度を定量的に測定できる。スチレン $\left[M_{1}\right]$ と他の単量体 $\left[M_{2}\right]$ との共重合 $\left.{ }^{4}\right)$ に括ける $\gamma_{1}$ 括よび $\gamma_{2}$ 值を次表に示す。

\begin{tabular}{c|c|c|c}
\hline \multicolumn{1}{c|}{$M_{2}$} & $\gamma_{1}$ & $\gamma_{2}$ & $\begin{array}{c}\text { 相対反応速度 } \\
\left(1 / \gamma_{1}\right) \\
\left(60 \sim 70^{\circ} \mathrm{C}\right)\end{array}$ \\
\hline スチ ン & - & - & 1.0 \\
メタクリル酸メチル & 0.5 & 0.5 & 2.0 \\
2.5 -ジクロルスチレン & 0.2 & 0.8 & 5.0 \\
アクリル酸メチル & 0.75 & 0.2 & 1.3 \\
クロロマレイン酸ジ & 2.5 & 0.0 & 0.4 \\
エチル & & 0.04 & 25 \\
無水マレイン酸 & 0.0 & 0.2 \\
マレイン酸ジェチル & 5.0 & 0.0 & 0.0 \\
アクリロニトリル & 0.37 & 0.05 & 2.7 \\
塩化ビニリデン & 2.00 & 0.14 & 0.50 \\
\hline
\end{tabular}

すなわちスチレンラジカルと他の単量体との反応によ る $\gamma_{1}$ の值はすべてスチレンラジカルとスチレンとの速 度定数で割った商にて表す。

表によりてあきらかなように，スチレンラジカルとメ
タアクリル酸メチルの反応速度はスチレンラジカルとス チレンとの反応速度の約 2 倍である。スチレンラジカル と無水マレイン酸の反応はきわめてはやく, 無水マレイ ン酸同志はほとんど反応しない。すなわちスチレンラジ カルに対してはメタアクリル酸メチル，2.5-ジクロルス チレン, 無水マレイン酸アクリロニトリルは反応性高く, クロロマレイン酸ジェチル，マレイン酸ジェチル，塩化 ビニリデンは反応性がひくい。

同様な表は他の単量体ラジカルに対しても得られてい

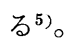

これ等の結論は特殊な選択性を示す場合を除き二種の 単量体より得られる共重合体の組成を知るのにきわめて 有効である。

\section{参 考 文 献}

1) A.G.Evans \& E. Tyrral ; J. Polymer Sci, 2, 387 (1947).

L. K. J. Tong \& W. O. Kenyon; J. Am. Chem. Soc., 67, 1278 (1945); 68, 1355 (1946).

2) 本山卓彦氏の実験結果による.

3) Mayo \& Lewis; J. Am. Chem. Soc., 66, 1594 (1944).

4) Bawn; The Chemistry of high polymers (1948).

5) K. Nozaki ; J.Polym. Science, 1, 455 (1946). Lewis, Mayo \& Hulse ; J. Am. Chem. Soc., 67, 1701 (1946).

\title{
不飽 和ポリエステル
}

\section{Unsaturated polyester}

\section{1. まえがき}

不飽和ポリエステルは, 通常二価の不飽和酸（マレイ ン酸，フマル酸）とグリコールを縮合し，できたポリエ ステルをスチレン単量体のような共重合成分に溶かした ものである。これは触媒や加熱炕よて，ポリエステル 中の不飽和基と共重合成分が重合し，交サ結合によって 三次元構造をとるので，不溶，不融性の固体になる。 この際共重合成分は溶剤としての役割をも果すので, 尿素，フェノールなどの樹脂のように，含浸や塗装する ために溶剤を加える必要がないし，また溶剂の乾燥工程

* 工業技術院東京工業試験所, 昭 33.12.5. 受理 $\overline{26 \quad[2]}$
牧 広*

MAKI Hirosi

も必要としない。な怙樹脂の硬化は重合反応によるの で，縮合型の樹脂と異り，水その他の副生物をともなわ ないから，成形の除に加圧する必要がないし，厚塗りを することもできる。

\section{2.＼cjkstart不飽和ポリエステルの種類}

現在アルキド型のものと,アリル型のものがあるが, 一般にはアルキド型が用いられ，アリル型は注とんど用 いられていない。

\section{1 不飽和アルキド型}

前述のよ5に不飽和二塩基酸とグリコールを縮合し， これを共重合成分に溶かしたものであって，つぎのよう 
に反応させる。

$\mathrm{CH} \cdot \mathrm{CO}$

$\| \stackrel{\mathrm{CH}}{\underset{\mathrm{CO}}{\mathrm{CO}} \mathrm{O}}+\mathrm{HOCH}_{2} \mathrm{CH}_{2} \mathrm{OH} \underset{-\mathrm{HO}_{2}}{\longrightarrow}$

無水マレイン酸 エチレングリコール

$\mathrm{H}-\left(-\mathrm{OOC} \cdot \mathrm{CH}=\mathrm{CH} \cdot \mathrm{COOCH}_{2} \mathrm{CH}_{2}-\right)_{i 0}-\mathrm{OH}$ 不飽和アルキド

不飽和アルキド+ (市販品の状態)

スチレン

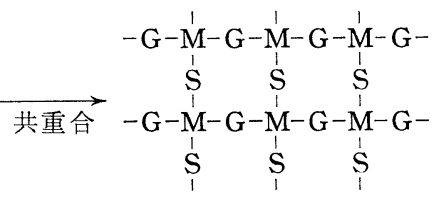

ただし $\mathrm{M}, \mathrm{G}$ はそれぞれマレイン酸执よびグリコール 残基，Sはスチレンを示す。

普通，酸もグリコールも単独で用いることはなく，各 種の飽和二塩基酸やグリコールで変性してある。したが ってそれだけでも多種類の樹脂ができる。また共重合成 分も各種のビニル化合物を用いることができるが, 沸点, 価格, 反応性などの条件によって, 現在実用されている のは，（a）スチレン，（b ）フタル酸ジアリル，（c）ト リアリルシアヌレート，（d）メタクリル酸メチルと酢 酸ビニルなどである。この中がもっと（a）も多く用い られて括り，普通スチレン系と呼ばれ，常温硬化させる ことができる。（b）はアリル系と呼ばれ，加熱硬化用 である。（c）は耐熱性が非常によく，500F までの強 度保持率が優れているといわれている。（d）は非常に 少なく，米国製樹脂のカタログに $1 ， 2$ の例があるにす ぎない。

\section{2 アリル型}

二価の酸とアリルアルコールを縮合したジアリルエス テルが用いられ，多種類のエステルが考觉られるが，実 際にはフタル酸ジアリルだけが市販された。

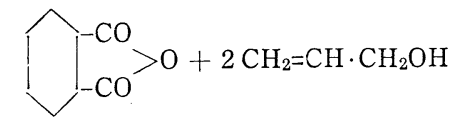

無水フタル酸音リルアルコール

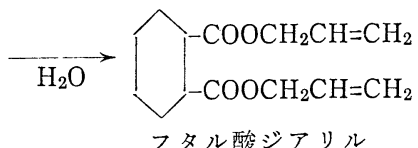

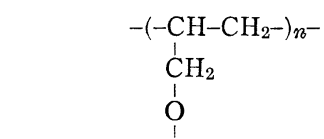

部分重合

CO<smiles>C=CCOC(=O)C1CCCCC1C</smiles><smiles>CCC(C)C</smiles>

このエステルはまず部分重合させ $(n$ は約 10$)$, 部分 重合物（アルキドに相当する）にフタル酸ジアリル単量 体を加え，さらに重合硬化させる方式をとっている。

アルキド型と異り，エステル基と不飽和残基は側鎖に ある。わが国では初期の頃この型のものが輸入された ‘，まだほとんど用いられていないようである。

\section{3. 不飽和ポリエステルの性質}

\section{1 長 所}

不飽和ポリエステルのもっとも大きな鬽力は，常温， 無圧でも硬化すること，厚塗りでさること，さらにガラ ス繊維を補強材とした強化プラスチックスの最適原料で あることとともに，強化プラスチックスそのものの趎力 も与っている。強化プラスチックスについては，あまり 述べない予定であるが, 構造材料, 強度メンバーになっ たはじめてのプラスチックスであり，乙かも加圧をこな くても済むので, 大型のもの（例党ばボートや自動車車 体など）が手軽に作れるという大きな利点がある。なお この樹脂は前述のように多種類のものが作りえるという ことも 1 つの長所であろ 5 。

\section{2 欠 点}

どんなによいものでも，またどのように魅力のあるも のでも，かならず欠点はあるものであり，また長所が欠 点になる場合もよくあることである。したがって，その 欠点をよく知り，それを解決してゆかなければよいもの はできない。

ここでは強化プラスチックスとしての欠点，難点には 触れないが，まず塗装の場合に気を付けなければならな いのは，触媒を用いる（焼付けの場合でも）ため，ぞう しても二液あるいは三液式になることである。しかも後 述するよ5に触媒の使用量が，せいぜい $1 \%$ 内外である ので,精確に計量するには相当の注意なり器具を要する。 このひとつの解決法として, わが国ではあるメーカーが 
現場施工用の樹脂を市販しているが，これは計量（特に 精度）の面倒な点を解決した例であって，非常に親切で ある。このような方法を塗装用樹脂にも応用してほしい ものである。

不飽和ポリエステルは，硬化すると収縮する。したが って特に厚叙りをする場合, そりの起る点に注意を要す る。またこの樹脂は空気中の酸素が硬化を妨げるので, 空気との接触面は, 硬化後べたつきが残る。したがって セロハンで塗面を覆い，空気との接触を断って硬化させ ているが，各メーカーでは，この解決法として空気硬化 性の樹脂を市販しているから，これを用いれば，七ロ八 ンなどを使う必要がない。しかしこれは樹脂の中に流動 パラフインのようなものが混入していて，樹脂の表面を 常に覆ら上うになっているから，もし重祖りをする場 合には研磨する必要がある。

つぎにこの樹脂は，過酸化物触媒で硬化させるので， 特に屋外用の場合顔料が制限されるのが大きな欠点で, 早く安定な, よい顔料ができてほしいものである。

一般的に不飽和ポリエステルは, 他の樹脂に比べて若 干もろい性質がある。そこで軟質の不飽和ポリエステル を混ぜて，もろさを改善する方法がとられることがある。

\section{4. 不飽和ポリエステル使用上の注意}

\section{1 硬化反応の調節}

不飽和ポリエステルの硬化は, 重合抑制剂, 安定剂な ぞで硬化を抑制し, 触媒, 促進剤で硬化させる。

(a) 重合抑制剂

原則として市販の樹脂には，かならず抑制剂が入って いる。普通用いられているのはヒドロキノンであるが， この他にもキノンや p-tert-ブチルカテュールなども抑 制効果がある。

(b) 安定剂

色材関係ではほとんぞ用いられないが，成形材料など では, 触媒をあらかじめ混入して执く必要があり, しか も可使時間の長いことが要求される。そのような場合に 用いられるもので， $4,4^{\prime}$-ジヒドロキシビフェニル，4, $4^{\prime}$ ージヒドロキシ-3,3-ジメチルビフェニルなどのような ビフェニル類が用いられる。

\section{(c) 重合触媒}

不飽和ポリエステルには, 通常過酸化物触媒が用いら れるが，もっとも代表的でよく使われているのは，過酸 化ベンジイルとメチルエチルケトンパーオキシドでめ る。前者はそのままでも用いられるが，扔执くの場合 TCP で練った 50\% ペースト (Luperco ATC そいう 商品名がある）が用いられ，後者は DMT の $60 \%$ 溶液

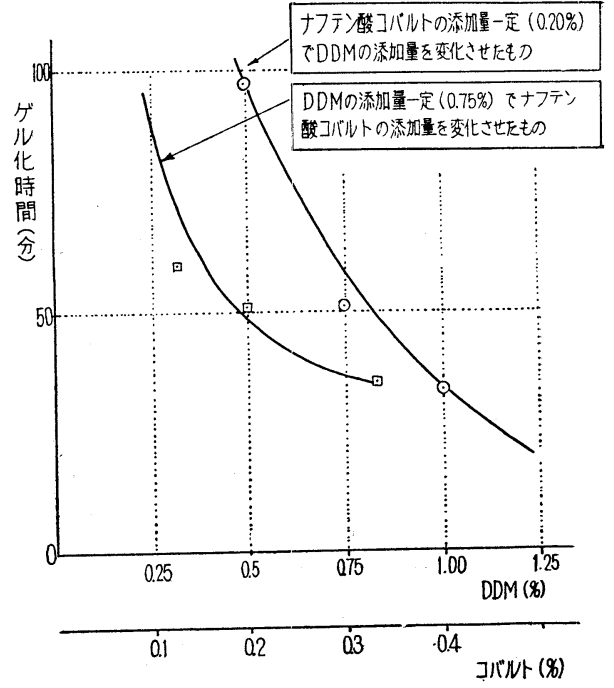

図 1 ある国産樹脂に対する触媒促進剤の添加量と ゲル化時間の関係

(Lupersol DDM という商品名がある) で用いられる。

(d) 重合促進剂

単独では触媒効果がないが，触媒を組合わせて用いる と硬化を促進し，常温で硬化する普通ナフテン酸コバル トか第 3 アミン（たと党ばジメチルアニリン）が用いら れるが，触媒との組合せには厳格な選択性があって，前 者は DDM，後者はATC と組合わせる。

な敃後者は着色する点もあり, 前者の方がもっとも多 く用いられている。

図 1 亿参考のため，ある国産樹脂に対する触媒，促進 剤の添加量とゲル化時間の関係を示す。この曲線はもち 論樹脂, 触媒の種類および温度が変れば変化する。

\section{2 その他の注意事項}

\section{(a) 室温と可使時間}

前述の上5に温度が変ると, 硬化速度は変化するので, 可使時間に注意する必要がある。また温度が変とる同時 飞粘度孔変化し，乙反达及の速度も变化する。

(b) 重亦りについて

空気硬化性樹脂を用いる場合, 重衫塗りはできるだけ 避けた方がよいが，必要な時は, 重㸚叙りをする前に研 磨する必要がある。

(c) 触媒の取扱い

触媒量は硬化速度に大きく影響し，乙か子使用量がわ ずかであるから，精度に注意しなければいけない。また 空気調節した工場ならともかく, 各温度と触媒量との関 係をよく知って扣く必要がある。な特過酸化物触媒は爆 発，火災などの危険もあるから，火気などに注意する必 要がある。 
(d) 顔料，充テン剂について

顔料が触媒の影響を受けて，変色する場合もあるが， 逆に顔料や充テン剂によって硬化速度が影響を受ける場 合もあるから注意する必要がある。

（e）光沢面の作り方

化粧板を作る時や厚塗りをする場合，ガラス面を使う と光沢面がえられるが，その場合離型剤のよいものを使 弓必要が岀る。

(f) 相溶性

市販樹脂にスチレンなぞを加えて，粘度を下げたり， 価格低下をはかる場合があるが，スチレン量は各メーカ 一が最適配合で市販しているものであるから，できるだ け加えないことが望ましい。また常識的な範囲ではほと んぞ問題にならないが，スチレンを非常に多量に加える と，不飽和アルキドが分離することもありえる。

なお他の樹脂との相溶性はあまりよくないようである。

\section{5. 不飽和ポリエステルの硬化}

通常過酸物触媒を用いて加熱硬化するが，スチレン系 の場合促進剤を用いると，常温でも硬化する。

その場合 DDM とナフテン酸コバルトの組合せ，また はATC と第 3 アミンの組合せが用いられるが，前者の 方がよく用いられらる。

不飽和ポリエステルの硬化は発熱反応である。SPI (The Society of the Plastics Industry, Idc.) では, この発熱反応による樹脂温度を測定し，硬化を定義して いる。

すなわち触媒を加えた樹脂 $100 \mathrm{~g}$ を調整し，これを $19 \mathrm{~mm} \times 150 \mathrm{~mm}$ の試験管の中へ, 深さ $76 \mathrm{~mm}$ (3 in) になるよ弓注ぎこみ，鉄コンスタンタン (No. 24) の熱 電対を厚さ $3.2 \mathrm{~mm}$ の黄銅製のサヤに入れて，上部の 樹脂の中に挿入する。この際サヤの先端は, 樹脂の丁度 中心になるようにする。

熱電対をポテンショメーターに接続し，試験管を恒温 ソウ $(82.2 \pm 0.3$

$\left.{ }^{\circ} \mathrm{C}\right)$ の中へ入れ, 試験管の樹脂の上 面が，恒温ソウの 水面より下になる ようにする。

樹脂はソウによ って加熱されて共 重合反応を開始 し，発熱反応なの で，図2のよ5に

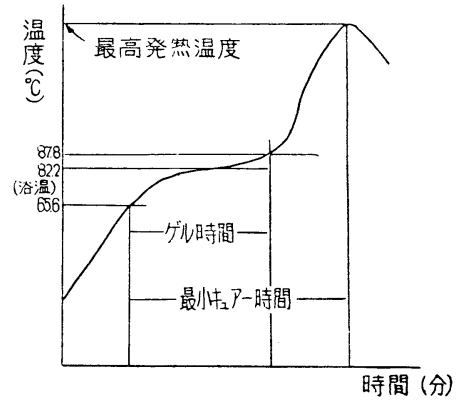

図 2 不飽和ポリエステル硬化の際 の発熱曲線
ソウの温度よりも高温になり，しばらくすると放熱して， またりウの温度にまで戻る。樹脂の温度が $65.6^{\circ} \mathrm{C}$ (ソウ の温度より $30^{\circ} \mathrm{F}$ 低い) から $87.8^{\circ} \mathrm{C}$ (ソウの温度より 10 ${ }^{\circ} \mathrm{F}$ 高い) に達するまでの時間をゲル化時間(Gel time), 樹脂の最到達温度を最高発熱温度 (Peak exotherm), $65.6^{\circ} \mathrm{C}$ から最高発熱温度までの時間を最小キュア一時 間 (Minimum Cure time) と定義する。な特試験は 3 回行って，その平均值をとる。

これらの值は，もち論各樹脂特有の值であり，また加 える触媒の種類执よび量によっても異るが，触媒につい ての規定はない。しかし各樹脂メーカーのカタログを通 覧すると，過酸化ベンゾイルを樹脂に対して $1 \%$ 加える のが普通のようである。

\section{6. 市販樹脂の種類}

不飽和ポリエステルは，各国，各メーカーで作られ， 非常に種類が多いが，これらを性能上で分類するつぎの ようになる。

一般用樹脂 もっとも普通に用いられている。

軟質樹脂 単独で用いることはなく, 他の樹脂に混ぜ て用い，もろさを改善するために使う。

空気硬化性樹脂 空気と接触しても, べたつきが残ら ない。

加熱硬化性樹脂 アリル系樹脂であって，加熱硬化さ せる場合に用いる。

耐炎性樹脂 炎に接している時は燃えるが，炎を遠さ けると火が消える，いわゆる自己消火性樹脂で，主 として塩素化合物を原料として括り，最も代表的な のが HET 酸で変性したものである。

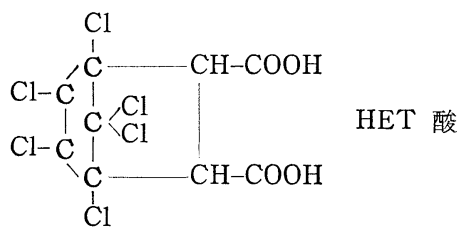

耐熱性樹脂 前述のトリアリルシアヌレートを共重合 成分にすると，高温でも十分な強度を持つプラスチ ックスが作れる。な持国産ではスチレン系で耐熱性 のある樹脂を市販している会社がある。

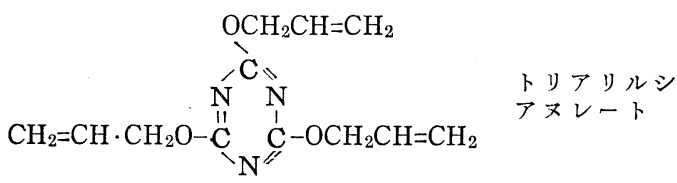

耐薬品樹脂 ライニングなどによく使われる。 耐光性樹脂 普通紫外線吸収色素が入っていて，屋外 などで使っても着色しないようになっている。

[2] 29 
注形用樹脂 最高発熱温度の低く, 収縮によるキレッやヒビなどの 入らないようになったもの。

チキソロピー樹脂

固形樹脂 米国 Atlas Powder

Co. 製の樹脂で，グリコールの

代りに, 次式のグリコールエー

テルを用いているようである。

これはスチレンに溶かして用い るようになっている。
接着用樹脂 ガラス纎維（マットやプリホームなど）

の接着用である。

な抗これらの中, 粘度や反応性, かたさなどによって さらに分類されているものもある。



表 1 各種構造材の強度比較

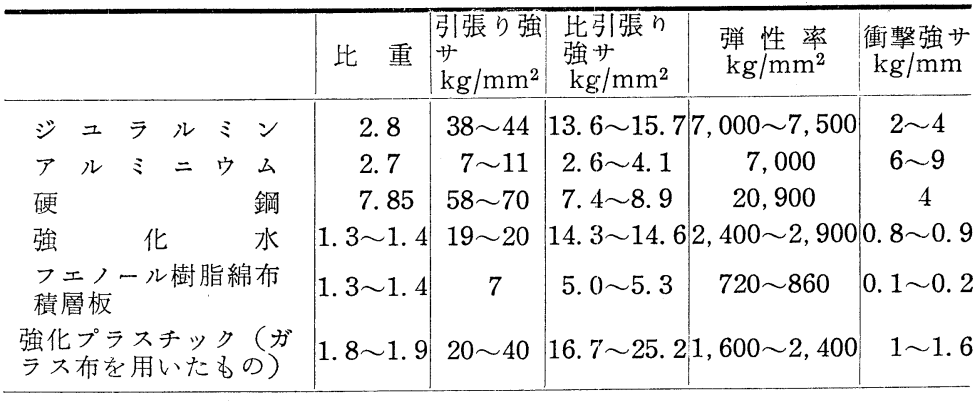

\section{7. 不飽和ポリエステルの応用面}

\section{1 塗装, ライニング, 化粧板}

色材工業に最も縁の深い応用面である。塗装は通常空 気硬化性樹脂を用いて，主として上塗りに用いられてい るが， 1,2 の塗料メーカーでパテを製造している。ライ ニングは耐薬品性樹脂とガラス布を用い，ホウロウびき

表 2 強化プラスチックス板の試験結果一覧表

（強化プラスチックス協会基本.部材委員会による国産品の試験結果）

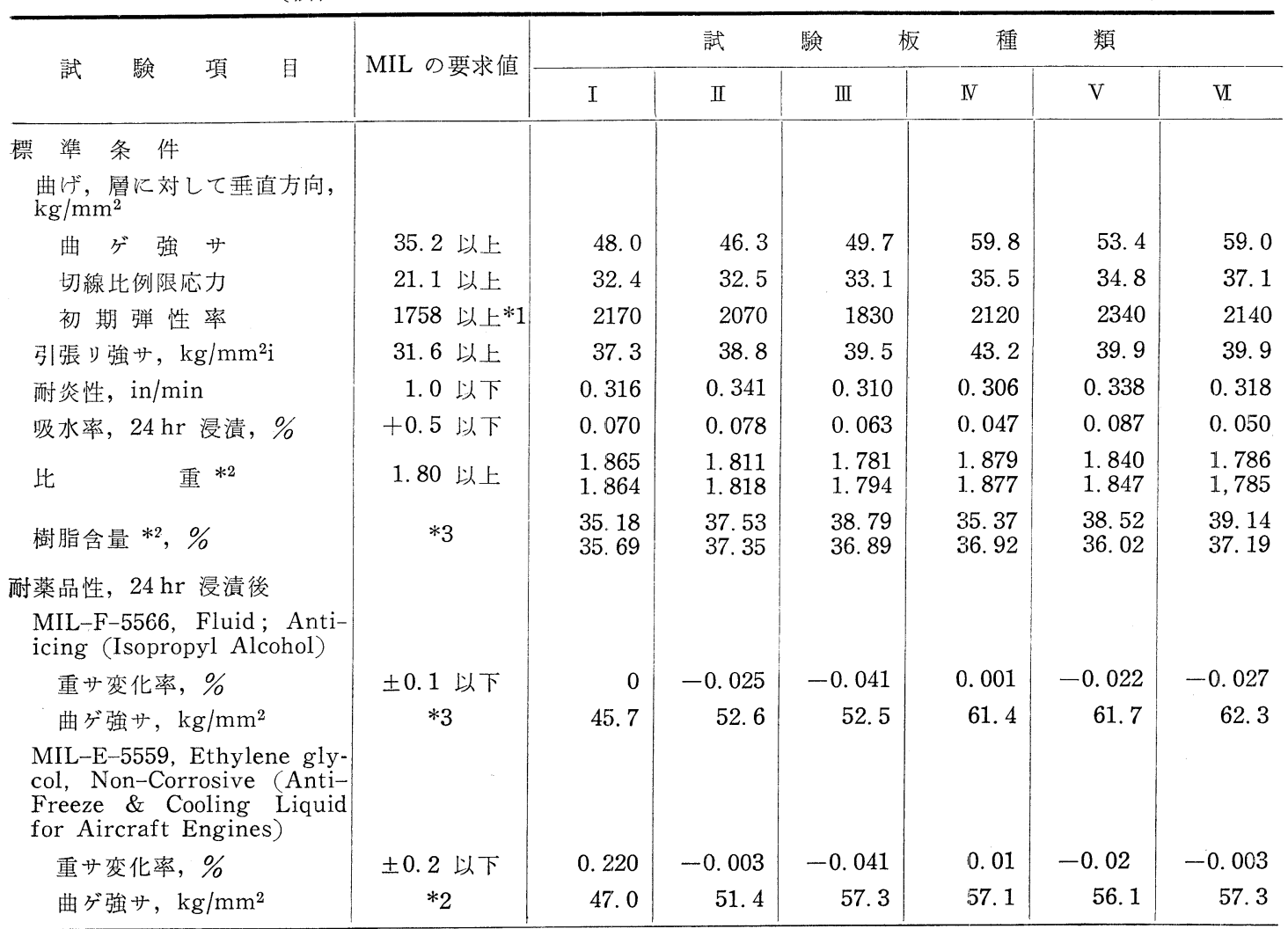

注 : *1 改訂規格 MIL-R-7575 A の要求值は $28.1 \mathrm{~kg} / \mathrm{mm}^{2}$

*2 試験板を 2 枚用いたので，データを区別した。上段が No. 1, 下段が No. 2 の試験板のデータで女る。

*3 要求值は規定されていないが, 試験することとその結果を報告することが要求されている。

$30[2]$ 
を拈き変えようとしているばかりでなく，たとえば木船 にライニングをして水もりを防いだり，強度を与える応 用面がある。化粧板は強化プラスチックス板を用いる場 合もめるが，デュラと同じように，紙や布を用いて美し い模様をだし，ベニア板やスレートにはる方法が注目さ れている。

\section{2 注形品}

現在メタクリル樹脂製のボタンを挔き変えているが， これはアイロンの熱に対してポリェステルが優れている からである。また電機メーカーでは, 電気部品を埋込久 注形し，立体的な回路を組立てている。

\section{4 強化プラスチックス}

強化プラスチックスは“アルミよりも軽く, 鉄よりも 強い”というキヤッチフレーズで紹介され, 世の注目を あびたが，このキヤッチフレーズのために非常な誤解が 起った。表 2 に各種構造材料の強度の比較を示したが, たしかに強度は大きく, ことに比強度（強度を比重で除 したもの）はすばらしくよい。しかしこれは高価なガラ ス布を用いた場合のことであって，一般に用いられてい るガラスマットでは, このようなすばらしい強度は示さ ない（通常引張りは 8〜 $5 \mathrm{~kg} / \mathrm{mm}^{2}$, ヤング率は 900〜 $1000 \mathrm{~kg} / \mathrm{mm}^{2}$ 程度)。また構造材料として用いる場合は, 弾性率の方が, 強度よりも重要なことが多く, しかも弾 性率は木材と大体同程度である。

ここでは強化プラスチックスについて述べる余裕がな
いので，後述する参考文献を参照されたいが，この材料 は全く“新しい料材”であって，金属や木材とは違うも のである。したがって金属その他の代用品として考学る べきでなく, “新しい材料”としての応用面，設計を考 えるべきものである。

表 2 に強化プラスチックス協会基本部材委員会で試験 した国産強化プラスチックス 6 種（昭和 30 年に叔ける 原料）の試験結果を参考のために示したが，これは国産 品の水準を試験するために行った試験結果で, 基材とし ては最高級に属するガラス布（朱子織）を用いたもので ある。この試験は米軍規格 MIL-R-7575 および改訂規 格 MIL-R-7575 A に準じて行ったものであるが，詳細 は同協会誌強化プラスチックス 4, No. 4, 199 (1958) を参照されたい。

参考文 献 (和書の文)

1）強化プラスチックス（強化プラスチックス協会機 関紙，年 6 冊)

2）強化プラスチックス協会編；強化プラスチックス （産業図書，1957）

3）秋田務; ポリエステル樹脂工業（誠文堂新光社, 1950)

4) 井本稔; ポリエステル樹脂（高分子化学刊行会, 1953)

5）大島敬治他；ポリエステル樹脂の成形加工（高分 子化学刊行会, 1954)

\section{業界ニュース}

389.6

第1 回標準化大会 1958.10.23 25. 東京産経会館 会館で, 日本規格協会。主催第 1 日: 開会式, 研究発表, 懇親会。第 2 日: 研究発表, 討論会。第 3 日: 見学。研 “究発表の5ち第 2 日 13.00 ～13.30 「我国に打ける塗料 の標準化」塩田良一氏。 $(\mathrm{H}-\mathrm{S})$

$535.65(083.7): 535.66$

JIS Z 8722-1958・物体色の測定方法 専門委員会案き まる 1958-12-12 の第 15 回専門委で決定全文清書のう え念の為も5一度書面審議にかけてから来初春の部会に 提出することになった。解説は委員中から関係部分を分 担する。委員長代行は東大の日置助教授。

$(\mathrm{H}-\mathrm{S})$
顔 料関 係 会議

工業技術院 JIS 専門委員会 チタン白 JIS 改正案容

議, 眊機顔料（リトポン・鉛白・鉛丹・ジンククロメー ト) JIS 改正案審議 34.1.22 日工薬

東部顔料技術研究会 総会 34.1 .24 於湯河原

東部顔料技術研究会拉術委員会; 幹專長選出, 無機 顔料 (黄鉛, 紺青, 群青) JIS 改正の件 34.2 .2 日 工薬 